Sonja Kaurin', MA

Originalni naučni rad

Univerzitet u Istočnom Sarajevu

UDK: 37.036

Filozofski fakultet Pale

Katedra za pedagogiju

Doc. dr Ranka Perućica ${ }^{2}$

Univerzitet u Istočnom Sarajevu

Medicinski fakultet Foča

\title{
SAMOPROCJENE KREATIVNOSTI KOD STUDENATA U ZAVISNOSTI OD NJIHOVOG POLA I AKADEMSKOG USPJEHA
}

\begin{abstract}
Rezime: Osim podataka o objektivnim pokazateljima kreativnosti, dosta informacija o kreativnosti ljudi mogu dati i podaci o tome kako oni sami vide i procjenjuju svoje kreativne potencijale. $U$ ovom istraživanju smo na uzorku od 305 studenata Kaufmanovom K-DOCS skalom mjerili samoprocjene kreativnosti u pet različitih oblasti njenog ispoljavanja, pa dobijene mjere povezali sa podacima o polu i akademskom uspjehu studenata. Veza sa polom registrovana je u lično-svakodnevnoj i umjetničkoj oblasti (bolje rezltate su postigle žene), te u tehničko-naučnoj oblasti (bolje rezultate su postigli muškarci). Kad je riječ o akademskom uspjehu, veze su registrovane sa akademskom i umjetničkom oblašću ispoljavanja kreativnosti (u oba slučaja bolje skorove su ostvarili studenti sa boljim uspjehom). Interakcija između pola i akademskog uspjeha registrovana je samo kod lično-svakodnevne oblasti. Dok se žene sa različitim akademskim uspjehom nisu razlikovala na planu rezultata u lično-svakodnevnoj oblasti, kod muškaraca su razlike registrovane (muški studenti sa boljim akademskim uspjehom ostvarili su više skorove).
\end{abstract}

Ključne riječi: kreativnost, K-DOCS skala, samoprocjene kreativnosti i pol, samoprocjene kreativnosti i akademski uspjeh.

\section{Teorijski okvir}

Nastanak i razvoj civilizacije, kao i opšti napredak čovječanstva, najvećim dijelom počivaju na mogućnosti čovjeka da otkriva, da saznaje stvarnost oko sebe i da svoje spoznaje pretače u najrazličitije proizvode vlastite djelatnosti. Za sve to je presudna sposobnost stvaralačkog, kreativnog odnosa prema svijetu. Ne navodi se bez razloga kreativnost (divergentna produkcija, stvaranje novih ideja) kao jedan od važnih kompetencija koje su ljudima neophodne u 21. vijeku (Suzić, 2000). Na sve to posebno svjetlo bacaju rezultati istraživanja koji pokazuju da je kreativno ponašanje moguće razvijati odgovarajućim vježbanjem (Kvaščev, 1983; Stojaković, 2000).

Ljudi će lako postići saglasnost o ogromnom značaju koju kreativni potencijal ima za svaku zajednicu, ali je postizanje saglasnosti oko prirode kreativnosti daleko teži zadatak. Na jednostavno pitanje šta je kreativnost postoji mnoštvo odgovora. Na osnovu uvida u literaturu

\footnotetext{
${ }^{1}$ sonja.kaurin@ff.ues.rs.ba

2rankaskrkar78@gmail.com
} 
koja se bavi kreativnošću Trefinger (Treffinger, 1996) izvještava o preko 100 definicija kreativnosti. U tom mnoštvu određenja kreativnosti nalaze se i takva koja su teško spojiva jedna sa drugima. Velš (Welsch, 1981) konstatuje kako se u literaturi mogu naći toliko različite definicije kreativnosti da je zadatak pronalaženja neke zajedničke definicije, koja bi ih sve obuhvatila - praktično neostvariv.

Po pravilu se kao bitno obilježje kreativnosti ističe potencijal za stvaranje nečeg novog (Benedek, Jauk, Sommer, Arendasy, \& Neubauer, 2014). U većini definicija kreativnosti u prvi plan se stavlja sposobnost za stvaranje novog, originalnog, nečega što nije obično, svakodnevno i stereotipno, što djeluje iznenađujuće i prevazilazi okvire uobičajenog razmišljanja i djelovanja (Barron, 1988).

U nedoumicama o prirodi kreativnosti važno mjesto zauzima i pitanje da li se radi o jedinstvenoj sposobnosti koja se manje-više jednako ispoljava u najrazličitijim oblastima (Plucker, 1988) ili je riječ o posebnim sposobnostima vezanim za konkretne oblasti njihovog ispoljavanja. Novija istraživanja ukazuju na niske korelacije među pokazateljima kreativnosti u različitim oblastima što ne govori u prilog koncepciji o kreativnosti kao jedinstvenoj sposobnosti (Baer, 2012; Kaufman \& Baer, 2004). Tako na značaju dobijaju teorijski pristupi koji kreativnost vide kao višedimenzionalnu sposobnost vezanu za posebne oblasti (Feldman, 1986; Gardner, 1983). Treba dodati da rezultati nekih istraživanja sugerišu da je kreativnost specifična za posebne oblasti, ali samo djelimično (Diakodoy \& Spanoudis, 2002; Han, 2003; Silvia, Kaufman, \& Pretz, 2009).

Različito se određuju oblasti ispoljavanja kreativnosti. Jedna od najčešće isticanih razlika je razlika između kreativnosti u oblasti nauke i kreativnosti u oblasti umjetnosti (Feist, 1998). Osim o te dvije oblasti, govori se i o nekim drugim, npr. o svakodnevnoj oblasti (Runco \& Bahleda, 1986); o oblasti empatije i komunikacija, oblasti ručnog rada i oblasti matematike i nauke (Kaufman \& Baer, 2004); o oblastima kao što su izvedba, rješavanje problema, vizuelna verbalna umjetnost, preduzetništvo, interpersonalni odnosi (Kaufman, 2006). Neki instrumenti za mjerenje kreativnosti konstruišu se sa ciljem da mjere kreativnost u većem broju oblasti. Takav je upitnik kreativnih postignuća (CAQ) koji obuhvata sljedeće oblasti: vizuelne umjetnosti, muzika, ples, arhitektura, kreativno pisanje, humor, pronalazaštvo, nauka, teatar i film, kulinarstvo (Carson, Peterson, \& Higgins, 2005). Kaufman konstatuje da ne postoji jedinstven model strukture kreativnosti (Kaufman, 2012).

Problemi koji se tiču određenja i strukture kreativnosti aktuelni su i kad je riječ o njenom mjerenju. Osnovno pitanje na tom planu je preko kojih pokazatelja mjeriti kreativnost. Silvija i saradnici razlikuju pet širokih kategorija: kreativni proizvodi, kreativna kognicija, kreativne osobine, kreativno ponašanje i kreativna dostignuća (Silvia, Wigert, Reiter-Palmon, \& Kaufman, 2012). Hocevar i Bečelor (Hocevar \& Bachelor, 1989) govore o osam različitih pristupa mjerenju kreativnosti gdje spadaju mjerenje preko kognitivnih testova, preko biografskih inventara, procjena kreativnosti proizvoda, eminentnost, mjerenje stavova i interesa, upitnici ličnosti, procjena kreativnih učinaka od strane drugih osoba i samoprocjene vlastitog kreativnog ponašanja. Vjerovatno su najbolji pokazatelji kreativnosti rezultati djelatnosti pojedinca koji su nastali samoinicijativno i nevezano za situacije mjerenja (Lubart, 1994), ali takav način dolaženja do pokazatelja kreativnosti nije praktičan. Mnogo je praktičnije pitati ispitanike da sami procijene neke aspekte vlastitog kreativnog ponašanja ili njegovih rezultata.

Razvijen je veći broj instrumenata za mjerenje samoprocjena kreativnosti. Takvi su npr. Inventar kreativnog ponašanja (Hocevar, 1980), Upitnik kreativnih postignuća (Carson, Peterson, \& Higgins, 2005), Biografski inventar kreativnog ponašanja (Silvia et al., 2021). Pitanje koje ostaje 
otvoreno kod takvog pristupa mjerenju kreativnosti jeste u kojoj mjeri ispitanici imaju tačan uvid u svoje kreativne potencijale (Priest, 2006).

Razumljivo je da kreativnost ljudi utiče na uspješnost u mnogim djelatnostima kojima se bave. Pedagoški zanimljivo pitanje kada je riječ o kreativnosti, jeste da li se kreativni potencijali razlikuju kod različitih grupa ljudi, odnosno da li se kreativnost i način njenog ispoljavanja razlikuje u zavisnosti od pripadnosti subjekata nekim biološkim ili socijalno-statusnim kategorijama. Pošto je polna pripadnost jedan od osnovnih identitetskih odlika ljudi, zanimljivo je pitanje o odnosu pola i kreativnosti. Laička zapažanja mnogih ljudi upućuju ih na zaključak da muškarci i žene nisu podjednako snalažljivi i vispreni u situacijama različitih vrsta. Naučna istraživanja ne daju jednoznačan odgovor na pitanje o polnim razlikama u kreativnosti. Rezultati nisu konzistentni. U nekim istraživanjima nisu registrovane razlike (Agarwal \& Kumari 1982; Alpaugh \& Birren, 1977; Jaquish \& Ripple, 1981; Potur \& Barkul, 2009), dok su u drugim razlike registrovane, pri čemu su nekad u korist žena (Bharadwaj, 1985; Flaherty, 1992; Warren \& Luria, 1972), a nekad u korist muškaraca (Chan, 2005; Kaufman, 2006; Ruth \& Birren, 1985). U jednoj široj analizi više od 80 studija o vezama pola i kreativnosti utvrđeno je da u nešto preko pola tih studija nisu registrovane razlike, a u preostalim studijama je u dvije trećine njih registrovana razlika u korist žena i u jednoj trećini u korist muškaraca (Baer, 1993). Dvije su orijentacije u objašnjavanju mogućih izvora za razlike u kreativnosti: biološka i sociokulturna. Neki istraživači ističu postojanje polnih razlika u strukturama centralnog nervnog sistema i u njegovom funkcionisanju (Fink \& Neubauer, 2006; Luders \& Toga, 2010), dok drugi ističu uticaj razlika u kognitivnim stilovima (Baron-Cohen, Knickmeyer, \& Belmonte, 2005) koje su uslovljene različitim podsticajima koje sredina upućuje djeci različitog pola. Pinker zaključuje da bi bilo pogrešno reći da je neki od polova generalno kreativniji od drugog, ali bi bilo pogrešno reći i da nema apsolutno nikakvih razlika (Pinker, 2009).

Još jedno važno pitanje jeste kakav je odnos između kreativnosti i obrazovnih postignuća učenika, odnosno studenata. Ovo je posebno važno imajući na umu postojane kritike upućene školi koje tu instituciju vide kao mjesto gdje se sputava ili bar nedovoljno podstiče razvoj kreativnih potencijala učenika. U zavisnosti od obuhvaćenih varijabli i metodološkog pristupa, dobijani su različiti rezultati. $U$ većem broju istraživanja se registruje povezanost između kreativnosti i akademskog uspjeha (Ai, 1999), pri čemu nisu svi pokazetelji kreativnosti povezani sa mjerama postignuća u svim predmetima. Getzels i Džekson (Getzels \& Jackson, 1962) su dobili podatke koji govore o sličnom akademskom uspjehu učenika koji su visoko inteligentni, a malo kreativni i učenika koji su prosječno inteligentni, a visoko kreativni. Osim za postignuće u nekim školskim predmetima, kreativnost se posebno javlja značajnim faktorom za postignuća u vannastavnim aktivnostima (Perleth \& Sierwald, 1993). U našem istraživanju posmatrali smo povezanost samoprocjena kreativnosti kod studenata sa njihovim polom i akademskim uspjehom.

\section{Metodološki okvir istraživanja}

Cilj istraživanja bio je ispitati razlike u samoprocjenama kreativnosti studenata na Kaufmanovoj K-DOCS skali u zavisnosti od njihovog pola i akademskog uspjeha.

Polazne hipoteze u našem istraživanju su:

1. Pretpostavljamo da će se studenti različitog pola i različitog akademskog postignuća razlikovati na svim subskalama Kaufmanove K-DOCS skale.

2. Pretpostavljamo da ni kod jedne oblasti ispoljavanja kreativnosti neće biti interakcije između pola i akademskog uspjeha. 
U sastav uzorka ušlo je 305 studenata Filozofskog i Medicinskog fakulteta Univerziteta u Istočnom Sarajevu. Struktura uzorka je takva da je bilo osjetno više ispitanika ženskog pola $(80 \%$ prema $20 \%$ ), što približno odgovara polnoj strukturi studenata na tim fakultetima. Sa Filozofskog fakulteta bilo je $45 \%$ ispitanika, a sa Medicinskog $55 \%$.

Podaci o polu i akademskom uspjehu u dotadašnjem toku studija prikupljeni su kraćim anketnim upitnikom. Za mjerenje samoprocjena kreativnosti korištena je Kaufmanova K-DOCS skala oblasti kreativnosti (Kaufman, 2012). Skala se sastoji od 50 ajtema koji predstavljaju opise najrazličitijih ponašanja ljudi. Na petostepenoj skali Likertovog tipa ispitanici procjenjuju koliko bi u svakom od tih ponašanja mogli biti kreativni u poređenju sa drugim ljudima istog uzrasta i sličnih životnih iskustava. Skala mjeri samoprocjene kreativnosti u pet različitih oblasti njenog ispoljavanja. Tih pet oblasti su: 1. Lično-svakodnevna (interpersonalna i intrapersonalna kreativnost i opšti kreativni stil života); 2. Akademska (kreativnost u intelektualnim aktivnostima i verbalno-lingvistička kreativnost); 3. Izvedbena (kretne aktivnosti, muzika i kreativno pisanje); 4. Tehničko-naučna (matematička i mehanička kreativnost); 5. Umjetnička (kreiranje u oblasti umjetnosti i procjena umjetničkih vrijednosti) (Kandemir \& Kaufman, 2019).

Svih pet subskala pokazuju dobru pouzdanost. Prvi broj za svaku subskalu predstavlja Kronbahalfa koeficijent pouzdanosti, a drugi test-retest koeficijent pouzdanosti dobijen retestiranjem nakon dvije sedmice od prve primjene instrumenta: lično-svakodnevna oblast $(0,86 ; 0,80)$, akademska oblast $(0,86 ; 0,76)$, izvedbena oblast $(0,87 ; 0,86)$, tehničko-naučna oblast $(0,86$; $0,78)$ umjetnička oblast $(0,83 ; 0,81)$ (Kaufman, 2012).

Objašnjavajući prirodu instrumenta u kontekstu odnosa između mjerenja kreativnosti i mjerenja samoprocjena kreativnosti, autor skale ističe da ona nije konstruisana da mjeri objektivnu kreativnost. Ona omogućuje uvid u to kako ljudi vide sopstvenu kreativnost (vjerovatno donekle i kako je vrednuju), ali ne predstavlja zamjenu za objektivne mjere kreativnosti (Kaufman, 2019).

U više istraživanja je provjeravana faktorska struktura K-DOCS skale na ispitanicima iz različitih kulturnih sredina. Više je takvih istraživanja koja su potvrdila opravdanost originalnog petofaktorskog modela (Awofala \& Fatade, 2015; Miroshnika, Shcherbakova, \& Kaufman, 2020; Tan, Tan, Cheng, Hashim, \& Ong, 2016; Sahin, 2016), dok su neka sugerisala da bi više opravdanja mogli imati modeli sa većim brojem oblasti ispoljavanja kreativnosti, odnosno da skala mjeri više od pet takvih oblasti. Tako se u istraživanju Kandemira i Kaufmana navodi da rezultati dobijeni na uzorku ispitanika u Turskoj sugerišu kao više opravdan model od devet umjesto originalnih pet faktora (Kandemir \& Kaufman, 2019). U tom istraživanju akademska oblast kreativnosti pokazala se kao jedinstven faktor, kao i u originalnom modelu, dok su se ostale oblasti razdvojile na po dva faktora. Tako su utvrdili da se lično-svakodnevna oblast može razdvojiti na svakodnevno interpersonalnu i svakodnevno intrapersonalnu, izvedbena na izvedbenoknjiževnu i izvedbeno-muzičku, tehničko-naučna na matematičku i mehaničko-naučnu, a umjetnička na umjetničko-likovnu i umjetničko-djelatnu. Budući da su među parovima faktora na koje su se razdvojili faktori originalnog modela registrovali relativno visoke korelacije, zaključili su da njihovi rezultati ne opovrgavaju korektnost originalnog petofaktorskog modela, nego sugerišu da je vjerovatno moguće govoriti o subfaktorima unutar bar nekih od pet faktora originalnog modela.

Mi smo u našem istraživanju primijenili K-DOCS skalu u izvornom obliku sa pet subskala. Provjera pouzdanosti subskala na našim rezultatima dala je sljedeće Kronbah-alfa koeficijente: ličnosvakodnevna oblast: 0,71 ; akademska oblast: 0,80 ; izvedbena oblast: 0,88 ; tehničko-naučna oblast: 0,87 i umjetnička oblast: 0,84. Podaci su prikupljeni krajem marta i početkom aprila 2021. godine. Ispitanici su popunjavali instrumente na časovima redovne nastave. Predočeno im je da će se prikupljeni podaci koristiti isključivo u naučne svrhe. Obrada podataka uključivala je 
testiranje razlike među aritmetičkim sredinama, jednofaktorsku analizu varijanse, dvofaktorsku analize varijanse različitih grupa i LSD test.

\section{Rezultati istraživanja}

Rezultati analize razlika prema polu ispitanika prikazani su u tabelama 1 i 2.

Tabela 1. Aritmetičke sredine i standardne devijacije skorova koje su na subskalama K-DOCS skale postigli ispitanici različitog pola

\begin{tabular}{lllll}
\hline Oblast & Pol & $\mathrm{N}$ & $\mathrm{M}$ & $\Sigma$ \\
\hline Li-Sv & $\mathrm{M}$ & 60 & 39,25 & 5,49 \\
& Ž & 245 & 40,82 & 5,19 \\
\hline Akad & $\mathrm{M}$ & 60 & 35,85 & 6,80 \\
& $\check{Z}$ & 245 & 35,15 & 7,08 \\
\hline Izved & $\mathrm{M}$ & 60 & 25,28 & 8,12 \\
& Ž & 245 & 25,68 & 10,04 \\
\hline Teh-Na & $\mathrm{M}$ & 60 & 24,65 & 6,51 \\
& Ž & 245 & 22,20 & 8,52 \\
\hline Umjet & $\mathrm{M}$ & 60 & 27,68 & 7,62 \\
& $\check{Z}$ & 245 & 30,59 & 7,44 \\
\hline
\end{tabular}

Napomena: Li-Sv: lično-svakodnevna oblast; Akad: akademska oblast; Izved: izvedbena oblast; Teh-Na: tehničko-naučna oblast; Umjet: umjetnička oblast.

Značajne razlike su konstatovane kod samoprocjena kreativnosti u lično-svakodnevnoj oblasti (bolje rezultate su postigli ispitanici ženskog pola), u tehničko-naučnoj oblasti (bolje rezultate postigli ispitanici muškog pola) i u umjetničkoj oblasti (i ovdje su bolje rezultate postigli ispitanici ženskog pola).

Tabela 2. Testiranje razlika među aritmetičkim sredinama skorova koje su na subskalama K-DOCS skale postigli ispitanici različitog pola

\begin{tabular}{lll}
\hline Oblast & $\mathrm{t}$ & $\mathrm{p}$ \\
\hline Li-Sv & 2,08 &, 039 \\
\hline Akad &, 69 &, 488 \\
\hline Izved &, 32 &, 749 \\
\hline Teh-Na & 2,45 &, 016 \\
\hline Umjet & 2,70 &, 007 \\
\hline
\end{tabular}

Napomena: Skraćenice za oblasti ispoljavanja kreativnosti imaju isto značenje kao u Tabeli 1.

Ovim je dio polazne hipoteze koji se odnosi na vezu samoprocjena kreativnosti i pola potvrđen djelimično. U tabelama 3 i 4 prikazani su rezultati analize razlika u zavisnosti od akademskog uspjeha ispitanika.

Tabela 3. Aritmetičke sredine i standardne devijacije skorova koje su na subskalama K-DOCS skale postigli ispitanici sa različitim akademskim uspjehom

\begin{tabular}{|c|c|c|c|c|c|c|c|}
\hline Ocjena & $\mathrm{N}$ & & Li-Sv & Akad & Izved & Teh-Na & Umjet \\
\hline \multirow{2}{*}{$6-7$} & \multirow{2}{*}{14} & $M$ & 38,29 & 32,86 & 24,71 & 23,21 & 27,07 \\
\hline & & $\Sigma$ & 5,090 & 3,780 & 10,630 & 8,550 & 6,878 \\
\hline \multirow{2}{*}{$7-8$} & \multirow{2}{*}{114} & $M$ & 40,10 & 34,09 & 25,71 & 21,95 & 28,99 \\
\hline & & $\Sigma$ & 5,139 & 7,049 & 10,265 & 8,596 & 7,251 \\
\hline \multirow{2}{*}{$8-9$} & \multirow{2}{*}{122} & $M$ & 40,91 & 35,84 & 26,05 & 23,29 & 30,43 \\
\hline & & $\Sigma$ & 5,139 & 7,333 & 8,924 & 7,876 & 7,394 \\
\hline \multirow{2}{*}{$9-10$} & \multirow{2}{*}{55} & $M$ & 41,05 & 37,15 & 24,60 & 22,73 & 31,98 \\
\hline & & $\Sigma$ & 5,820 & 6,378 & 10,010 & 8,155 & 8,259 \\
\hline
\end{tabular}




\begin{tabular}{llllllll}
\hline \multirow{2}{*}{ Ukupno } & \multirow{2}{*}{305} & $M$ & 40,51 & 35,29 & 25,60 & 22,68 & 30,02 \\
\cline { 2 - 7 } & \multirow{2}{*}{5} & 5,278 & 7,019 & 9,685 & 8,213 & 7,550 \\
\hline
\end{tabular}

Napomena: Li-Sv: lično-svakodnevna oblast; Akad: akademska oblast; Izved: izvedbena oblast; Teh-Na: tehničko-naučna oblast; Umjet: umjetnička oblast.

Rezultati Lavenovog testa pokazali su da nije narušena pretpostavka o homogenosti varijense: Li-Sv $(0,518 ; r=0,670)$, Akad $(2,206 ; r=0,087)$, Izved $(1,373 ; r=0,251)$, Teh-Na $(0,518 ; r=0,670)$, Umjet $(0,717 ; r=0,542)$.

Značajne razlike su kod akademske i umjetničke oblasti, pritom je u oba slučaja, prema Koenovom kriterijumu, uticaj razlike mali (eta - koeficijenti su manji od o,06).

Tabela 4. Rezultati F - testova za skorove koje su na subskalama K-DOCS skale postigli ispitanici sa različitim akademskim uspjehom

\begin{tabular}{|c|c|c|c|c|c|c|c|}
\hline Oblast & $\begin{array}{l}\text { Izvor } \\
\text { varijabiliteta }\end{array}$ & $\begin{array}{l}\text { Sume } \\
\text { kvadrata }\end{array}$ & $\mathrm{df}$ & $\sigma^{2}$ & $\mathrm{~F}$ & $p$ & $\eta^{2}$ \\
\hline \multirow{3}{*}{ Li-Sv } & Između grupa & 124,570 & 3 & 41,523 & 1,498 & ,215 & \\
\hline & Unutar grupa & 8345,640 & 301 & 27,726 & & & \\
\hline & Ukupno & 8470,210 & 304 & & & & \\
\hline \multirow{3}{*}{ Akad } & Između grupa & 474,469 & 3 & 158,156 & 3,282 &, 021 &, 032 \\
\hline & Unutar grupa & 14503,714 & 301 & 48,185 & & & \\
\hline & Ukupno & 14978,184 & 304 & & & & \\
\hline \multirow{3}{*}{ Izved } & Između grupa & 91,991 & 3 & 30,664 &, 325 & 807 & \\
\hline & Unutar grupa & 28423,209 & 301 & 94,429 & & & \\
\hline & Ukupno & 28515,200 & 304 & & & & \\
\hline \multirow{3}{*}{ Teh-Na } & Između grupa & 110,241 & 3 & 36,747 &, 542 & ,654 & \\
\hline & Unutar grupa & 20395,909 & 301 & 67,760 & & & \\
\hline & Ukupno & 20506,151 & 304 & & & & \\
\hline \multirow{3}{*}{ Umjet } & Između grupa & 474,180 & 3 & 158,060 & 2,823 & ,039 &, 027 \\
\hline & Unutar grupa & 16854,738 & 301 & 55,996 & & & \\
\hline & Ukupno & 17328,918 & 304 & & & & \\
\hline
\end{tabular}

Napomena: Skraćenice za oblasti ispoljavanja kreativnosti imaju isto značenje kao u Tabeli 3.

LSD test je pokazao da se $u$ akademskoj oblasti ispoljavanja kreativnosti najbolji studenti (sa prosječnim opštim uspjehom između 9 i 10) značajno razlikuju od slabijih (sa uspjehom između 6 i 7 i onih sa uspjehom između 7 i 8) na nivoima značajnosti 0,040, odnosno 0,008. Studenti sa uspjehom između 8 i 9 nisu se razlikovali od ostalih grupa. Iz aritmetičkih sredina je vidljiva tendencija da su samoprocjene kreativnosti u akademskoj oblasti veće kod studenata sa boljim akademskim uspjehom. Ista tendencija je i u umjetničkoj oblasti. I kod ove oblasti studenti sa najboljim akademskim uspjehom imaju značajno bolje samoprocjene kreativnosti od studenata iz grupa sa slabijim akademskim uspjehom (razlika u odnosu na grupu sa prosječnom ocjenom između 6 i 7 je značajna na nivou 0,029, a u odnosu na grupu sa uspjehom između 7 i 8 je značajna na nivou 0,016). I kod umjetničke oblasti se studenti sa opštim uspjehom između 8 i 9 nisu razlikovali značajno od ostalih grupa. Time je dio polazne hipoteze koji se tiče veze između samoprocjena kreativnosti i akademskog uspjeha potvrđen manjim dijelom - samo kad je riječ o akademskoj i umjetničkoj oblasti.

Dvofaktorskom analizom varijanse različitih grupa provjerili smo postojanje interakcije između pola i akademskog uspjeha, kada je riječ o samoprocjenama kreativnosti na subskalama K-DOCS skale. Interakcija je utvrđena samo kod lično-svakodnevne oblasti $(F=3,46 ; d f=3 / 297 ; p=$ 0,017 ). Uticaj interakcije je mali (parcijalni eta koeficijent $\eta_{2}=0,034$ ). Grafikon 1 prikazuje karakter interakcije. 


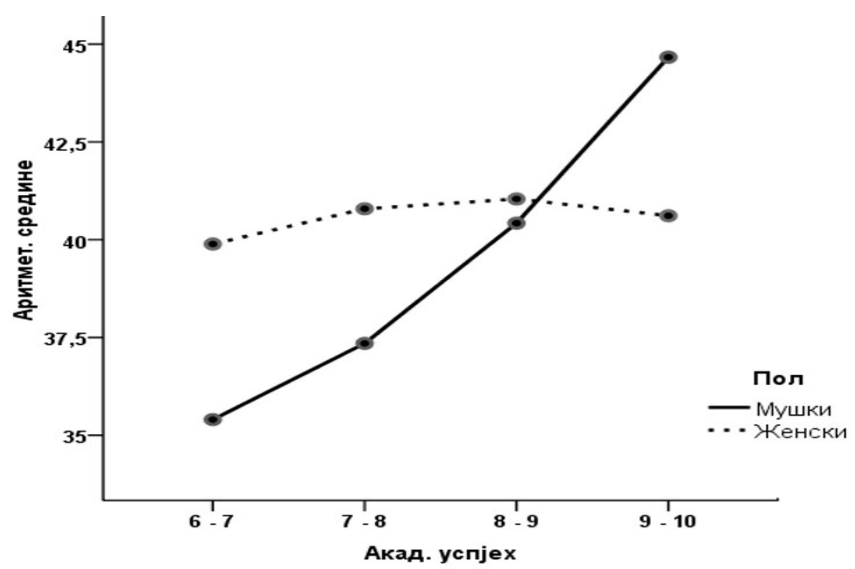

Grafikon 1. Aritmetičke sredine skorova koje su na subskali samoprocjene kreativnosti u ličnosvakodnevnoj oblasti postigli ispitanici različitog pola i različitog opšteg akademskog uspjeha

Kao što je iz dijagrama vidljivo, za razliku od ispitanika ženskog pola, muškarci se razlikuju u samoprocjenama kreativnosti u zavisnosti od akademskog uspjeha. To pokazuju i rezultati jednofaktorske analize varijanse posebno za ženske, posebno za muške ispitanike. Za ženske ispitanike rezultati su sljedeći: Lavenov test homogenosti varijansi $(0,707 ; r=0,549)$, i $F$ - test ( $F$ $=0,18 ; \mathrm{df}=3 / 241 ; r=0,910)$. Rezultati za muške ispitanike su sljedeći: Lavenov test homogenosti varijansi $(0,510 ; r=0,677)$, i $F$ - test $(F=4,89 ; d f=3 / 56 ; r=0,004)$. Kod ispitanika muškog pola sa porastom akademskog uspjeha rastu i samoprocjene kreativnosti u lično-svakodnevnoj oblasti. Kod ispitanika ženskog pola takva tendencija nije registrovana. Prema tome, većim dijelom možemo prihvatiti dio polazne hipoteze koji se odnosi na nepostojanje interakcije između pola i akademskog uspjeha. Ovo ne važi jedino kod lično-svakodnevne oblasti. U toj oblasti ispoljavanja kreativnosti interakcija je registrovana.

\section{Diskusija i zaključci}

Istraživanja o polnim razlikama u kreativnosti nekad daju nekonzistentne rezultate (Abraham, 2016; Baer \& Kaufman, 2008). U nekim istraživanjima nisu registrovane polne razlike u rezultatima na K-DOCS skali (Kapoor, Reiter-Palmon, \& Kaufman, 2021). Neka istraživanja registruju takve razlike. Mirošnika i saradnici su na ruskim ispitanicima utvrdili da na K-DOCS skali ženski ispitanici bolje rezultate postižu na subskalama koje mjere samoprocjene u sljedećim oblastima: lično-svakodnevna, akademska, izvedbena i umjetnička, dok su muški ispitanici bolje rezultate postigli na subskali koja mjeri samoprocjene kreativnosti u tehničkonaučnoj oblasti (Miroshnika, Shcherbakova, \& Kaufman, 2020). Koristeći drugi instrument za mjerenje samoprocjena kreativnosti, Kaufman je na većem uzorku ispitanika utvrdio da žene više vredniju vlastitu kreativnost u oblasti komunikacionih vještina i vizuelnih umjetnosti, dok muškarci više vrednuju svoju kreativnost u oblasti nauke i sporta (Kaufman, 2006). U nekoliko istraživanja je registrovano da žene više vrednuju svoju kreativnost u umjetnosti, a muškarci u matematici i naukama (Kaufman et al., 2010; Werner, Tang, Kruse, Kaufman, \& Sporrle, 2014). Kada procjenjuju uključenost u kreativne aktivnosti, žene izrazito češće izvještavaju o uključenosti u aktivnosti iz oblasti umjetnosti i ručnog rada, a muškarci o uključenosti u aktivnosti iz oblasti nauke i tehnike (Diedrich et al., 2018). Naši rezultati se dosta dobro slažu sa takvom konstatacijom. Utvrdili smo da su ženski ispitanici postigli bolje rezultate na subskali za lično-svakodnevnu i umjetničku oblast, dok su muški ispitanici bolje rezultate postigli na subskali za tehničko-naučnu oblast. 
Kada se u literaturi razmatraju veze između kreativnosti i akademskog uspjeha, redovno se polazi od opšte kreativnosti. Rezultati istraživanja nisu uvijek saglasni. U nekim istraživanjima se konstatuju manje ili više izražene pozitivne korelacije, dok se u nekim istraživanjima korelacije ne registruju. Kreativne sposobnosti mogu biti pozitivan prediktor obrazovnih postignuća, odnosno među njima se registruje pozitivna korelacija (Mourgues, Tan, Hein, Elliott, \& Grigorenko, 2016; Nami, Marsooli, \& Ashouri, 2014; Silvia, Wigert, Reiter-Palmon, \& Kaufman, 2012; Zheng \& Xiao, 1983). Neki autori izvještavaju o povezanosti srednjeg intenziteta između kreativnosti i uspjeha u posebnim oblastima, konkretno postignuća u stranom jeziku (Pishghadam, Khodadady, \& Zabihi, 2011). U nekim istraživanjima veza između kreativnosti i akademskog postignuća nije registrovana ili je ona zanemarljivo mala (Bučić i Sorić, 2002; Naderi, Abdullah, Aizan, Sharir, \& Kumar, 2010). Ljubotina i saradnici su primjenjivali instrument vlastite konstrukcije koji mjeri samoprocjene kreativnosti srednjoškolaca u četiri oblasti (izrada originalnih predmeta, likovne i tehničke kreacije, literarno-dramske kreacije, kreacije u području muzike i igre). Ni za jednu oblast nisu registrovali povezanost sa prosječnim školskim uspjehom (Ljubotina, Juničić i Vlahović-Štetić, 2015).

Složene odnose između kreativnosti i školskog postignuća usložnjava i to što veze kreativnosti i uspjeha zavise i od toga koji segmenti uspjeha se razmatraju. Izgleda da kreativnost nije jednako povezana sa uspjehom u različitim oblastima. Pekić (2011) je registrovao intenzivniju vezu između kreativnosti i uspjeha u društveno-jezičkim predmetima u odnosu na vezu između kreativnosti i uspjeha u prirodno-matematičkim predmetima.

Naši rezultati podržavaju stav o složenoj prirodi veza između kreativnosti i uspjeha ljudi u različitim aktivnostima. Pokazatelji kreativnosti su nam bile procjene ispitanika o vlastitoj kreativnosti, a uspjeh se odnosio na akademsko postignuće studenata. To postignuće nije pokazalo povezanost sa samoprocjenama kreativnosti u lično-svakodnevnoj, izvedbenoj i tehničko-naučnoj oblasti, a jeste sa samoprocjenama kreativnosti u akademskoj i umjetničkoj oblasti. Takav rezultat potvrđuje da je, umjesto analiziranja veze između uspjeha u nekoj oblasti i opšteg pokazatelja kreativnosti, pravilnije uspjeh dovoditi u vezu sa pokazateljima kreativnosti u posebnim oblastima njenog ispoljavanja. Povezanost akademskog uspjeha sa samoprocjenama ispitanika o vlastitoj kreativnosti u akademskoj oblasti je prirodna i očekivana. Interesantan je rezultat o povezanosti između samoprocjena kreativnosti u umjetničkoj oblasti i akademskog uspjeha. Taj rezultat nas navodi na misao da se uzrok povezanosti može tražiti u činjenici da su značajan dio ispitanika činili studenti čiji studij ima direktne ili indirektne veze sa umjetnošću (npr. studenti koji studiraju različite književnosti). Dok izraženija kreativnost u akademskoj oblasti može svim studentima biti od pomoći u postizanju boljeg uspjeha na studiju, izraženija kreativnost u umjetničkoj oblasti može biti od pomoći onima čiji profil studija ima veze sa umjetnošću. U prilog ovome govori i činjenica da kod studenata medicine takva veza nije registrovana. Posebno smo jednofaktorskom analizom varijanse testirali razlike u samoprocjenama kreativnosti kod studenata medicine (vrsta studija koja nema direktne veze sa umjetnošću). Razlike u umjetničkoj oblasti ispoljavanja kreativnosti u zavisnosti od akademskog uspjeha kod te podgrupe ispitanika nisu registrovane $(F=1,99, d f=3 / 97 ; p=0,12)$. Imajući na umu prethodno rečeno o složenosti veza kreativnosti i sa polom i sa akademskim uspjehom, nije jednostavno tumačiti rezultate koje smo dobili o interakciji pola i uspjeha na planu njihovih odnosa sa kreativnošću u lično-svakodnevnoj oblasti. Treba se podsjetiti da studenti ženskog pola prosječno postižu značajno više skorove na subskali koja se odnosi na tu oblast ispoljavanja kreativnosti. Izgleda da kod muškaraca kreativni potencijali u interpersonalnoj i intrapersonalnoj oblasti (koje su objedinjene u lično-svakodnevnoj) imaju veći uticaj na njihovo akademsko postignuće. Kod žena, koje pokazuju više samoprocjene kreativnosti u toj oblasti, neki drugi faktori su od većeg značaja. Bilo bi zanimljivo posebno mjeriti interpersonalnu i posebno intrapersonalnu komponentu kreativnosti (ranije je 
pomenuto da neki istraživači smatraju da je takav pristup opravdan), pa provjeriti postojanje interakcije pola i akademskog postignuća na tim odvojenim podoblastima lično-svakodnevne oblasti.

\section{Pedagoške implikacije}

Kreativnost jeste faktor koji ima uticaja na akademko postignuće, ali to važi za kreativnost u određenim oblastima - u onim oblastima koje se posebno vrednuju u obrazovnim institucijama. Osobe čija kreativnost se ispoljava u nekim drugim oblastima, sa stanovišta akademskog uspjeha, neće imati mnogo koristi od svoje kreativnosti. Ovo nas upućuje na oprez kada razmatramo i problem uticaja kreativnosti na akademsko postignuće i problem podsticanja kreativnosti u obrazovnim institucijama. Zbog prirode i načina funkcionisanja škola i univerziteta, neke vrste kreativnosti nam najčešće ostaju izvan vidokruga. Sve to se dodatno komplikuje činjenicom da, bar kad je riječ o nekim oblastima ispoljavanja kreativnosti, uticaj imaju i razlike među polovima.

\section{Ograničenja istraživanja}

Najvažnije ograničenje našeg istraživanja odnosi se na strukturu uzorka. U njegov sastav ušli su studenti iz dvije različite oblasti (medicinska i društveno-humanistička). To nam daje ograničene mogućnosti generalizacije na opštu studentsku populaciju, posebno kada se ima na umu da neka istraživanja pokazuju da se samoprocjene kreativnosti u različitim oblastima razlikuju u zavisnosti od obrazovnog profila ispitanika (Kandemir \& Kaufman, 2019). Dalje, poznato je da se u mnogim istraživanjima registruje određena povezanost između kreativnosti $i$ inteligencije. Sa druge strane, inteligencija je povezana sa akademskim postignućem. Ako se istražuju veze kreativnosti sa akademskim uspjehom bez kontrole inteligencije, ostaje nedoumica u kojoj mjeri utvrđene veze predstvaljaju direktnu povezanost, a u kojoj je ona posredovana inteligencijom. U nekoj mjeri ovo vjerovatno važi i kada se umjesto pokazatelja kreativnosti koriste pokazatelji samoprocjena kreativnosti. Mi u našem istraživanju nismo uključili takvu kontrolu.

\section{Literatura:}

Abraham, A. (2016). Gender and creativity: An overview of psychological and neuroscience literature. Brain Imaging and Behavior, 10 (2), 609-618. doi: 10.1007/s11682-015-9410-8

Agarwal, S., \& Kumari, S. (1982). A correlational study of risk-taking and creativity with special reference to sex differences. Indian Educational Review, 17, 104-110.

Ai, X. (1999). Creativity and Academic Achievement: An Investigation of Gender Differences. Creativity Research Journal, 12 (4), 329-337.

Alpaugh, P. K., \& Birren, J. E. (1977). Variables affecting creative contributionsacross the adult life span. Human Development, 20, 240-248.

Awofala, A. O. A., \& Fatade, A. O. (2015). Validation of the Domains of Creativity Scale for Nigerian Preservice Science, Technology, and Mathematics Teachers. Electronic Journal of Research in Educational Psychology, 13 (1), 131-150. doi:10.14204/ejrep.35.14057.

Baer, J. (1993). Creativity and Divergent Thinking: A task specific approach. Hillsdale, NJ: Erlbaum.

Baer, J., \& Kaufman, J. C. (2008). Gender differences in creativity. Journal of Creative Behavior, 42 (2), 75-106.

Baer, J. (2012). Domain specificity and the limits of creativity theory. Journal of Creative 
Behavior, 46 (1), 16-29. doi: 10.1002/jocb.002

Baron-Cohen, S., Knickmeyer, R. C., \& Belmonte, M. K. (2005). Sex differences in the brain: implications for explaining autism. Science, 310, 819-823. doi:10.1126/science.1115455.

Barron, F. (1988). Putting creativity to work. In: R. J. Sternberg (Ed.), The nature of creativity: Contemporary psychological perspectives (pp. 46-98). New York: Cambridge University Press.

Benedek, M., Jauk, E., Sommer, M., Arendasy, M., \& Neubauer, A. C. (2014). Intelligence, Creativity, and Cognitive Control: the Common and Differential Involvement of Executive Functions in Intelligence and Creativity. Intelligence, 46 (1), 73-83.

Bharadwaj, R. (1985). Intelligence, sex, and age as correlates of the components of creativity. Asian Journal of Psychology and Education, 16, 41-44.

Bucic, A., Soric, I. (2002). Kreativnost, inteligencija i skolski uspjeh. Razdio filozofije, psihologije, sociologije i pedagogije, 41(18), 117-142.

Carson, S. C., Peterson, J. B., \& Higgins, D. M. (2005). Reliability, Validity, and Factor Structure of the Creative Achievement Questionnaire. Creativity Research Journal, 17 (1), 37-50. doi: 10.1207/s15326934cri1701_4

Chan, D.W. (2005). Self-perceived creativity, family hardiness, and emotional intelligence of Chinese gifted students in Hong Kong. Journal of Secondary Gifted Education, 16, 4756.

Diakodoy, I. N., \& Spanoudis, G. (2002). The issue of domain specificity in creativity testing: A comparison of performance on a general divergent-thinking test and a prallel contentspecific test. Jouranl of Creative Behavior, 36 (1), 41-46.

Diedrich, J., Jauk, E., Silvia, P. J., Gredlein, J. M., Neubauer, A. C., \& Benedek, M. (2018). Assessment of real-life creativity: The Inventory of Creative Activities and Achievements (ICAA). Psychology of Aesthetics, Creativity, and the Arts, 12 (3), 304-316. doi: 10.1037/aca0000137

Feist, G. J. (1998). A meta-analysis of personality in scientific and artistic creativity. Personality and Social Psychology Review, 2 (4), 290-309. doi: 10.1207/s15327957pspro204_5

Feldman, D. H. (1986). Nature's Gambit. New York: Basic Books.

Fink, A., \& Neubauer, A. C. (2006). EEG alpha oscillations during the performance of verbal creativity tasks: differential effects of sex and verbal intelligence. International Journal of Psychophysiology: Official Journal of the International Organization of Psychophysiology, 62 (1), 46-53. doi:10.1016/j.ijpsycho.2006.01.001.

Flaherty, M. A. (1992). The effects of holistic creativity programs on the selfconcept and creativity third graders. The Journal of Creative Behavior, 26 (3), 165-171.

Gardner, H. (1983). Frames of Mind: The Theory of Multiple Intelligence. New York: Basic Books.

Getzels, J. W., \& Jackson, P. W. (1962). Creativity and intelligence: Explorations with gifted students. New York: Wiley.

Han, K. S. (2003). Domain-specificity of creativity in young children: How quantitative and qualitative data support it. The Journal of Creative Behavior, 37 (2), 117-142.

Hocevar, D. (1980). Intelligence, divergent thinking, and creativity. Intelligence, 4 (1), 25-40.

Hocevar, D., \& Bachelor, P. (1989). A taxonomy and critique of measurements used in the study of creativity. In: J. A. Glover, R. R. Ronning, C. R. Reynolds (Eds.), Handbook of creativity (pp. 53-75). New York: Plenum Press.

Jaquish, G. A., \& Ripple, R. E. (1981). Cognitive creative abilities and selfesteem across the adult life-span. Human Development, 24, 110-119.

Kandemir, M. A., \& Kaufman, J. C. (2019). The Kaufman domains of creativity scale: Turkish validation and relationship to academic major. The Journal of Creative Behavior, 54 (4), 1002-1012. doi: $10.1002 /$ jocb. 428 
Kapoor, H., Reiter-Palmon, R., \& Kaufman, J. C. (2021). Norming the Muses: Establishing the Psychometric Properties of the Kaufman Domains of Creativity Scale, Journal of Psychoeducational Assessment [Manuscript accepted for publication]. Preuzeto sa: https://www.researchgate.net/publication/350585056_Norming_the_Muses_Establi shing_the_Psychometric_Properties_of_the_Kaufman_Domains_of_Creativity_Scal e, 29.5.2021. doi:10.1177/07342829211008334

Kaufman, J. C., \& Baer, J. (2004). Sure, I'm creative but not in mathematics! Self-reported creativity in diverse domains. Empirical Studies of the Arts, 22 (2), 143-155.

Kaufman, J. C. (2006). Self-reported differences in creativity by ethnicity and gender. Applied Cognitive Psychology: The Official Journal of the Society for Applied Research in Memory and Cognition, 20 (8), 1065-1082. doi: 10.1002/acp.1255

Kaufman, J. C. (2006). Self-reported differences in creativity by ethnicity and gender. Applied Cognitive Psychology, 20 (8), 1065-1082. doi: 10.1002/acp.1255.

Kaufman, J. C., Waterstreet, M. A., Ailabouni, H. S., Whitcomb, H. J., Roe, A. K., \& Riggs, M. (2010). Personality and self-perceptions of creativity across domains. Imagination, Cognition and Personality, 29 (3), 193-209. doi: 10.2190/IC.29.3.C

Kaufman, J. C. (2012). Counting the muses: Development of the Kaufman domains of creativity scale (K-DOCS). Psychology of Aesthetics, Creativity, and the Arts, 6 (4), 298-308. doi: 10.1037/a0029751

Kaufman, J. C. (2019). Self assessments of creativity: Not ideal, but better than you think. Psychology of Aesthetics, Creativity, and the Arts, 13 (2), 187-192.

Kvascev, R. (1983). Razvijanje kreativnog ponasanja licnosti. Sarajevo: Zavod za udzbenike nastavna sredstva.

Lubart, T. I. (1994). Creativity. In: R. J. Sternberg (Ed.), Thinking and problem solving, (pp.289332). New York: Academic Press.

Luders, E., \& Toga, A. W. (2010). Sex differences in brain anatomy. Progress in Brain Research, 186, 3-12. doi:10.1016/B978-0-444-53630-3.00001-4.

Ljubotina, D., Junicic N., Vlahovic-Stetic, V. (2015). Struktura i prediktori samoprocjene kreativnosti kod srednjoskolaca. Psihologijske teme, 24 (3), 369-399.

Miroshnika, K, G., Shcherbakova, O, V., \& Kaufman, J. C. (2020). Kaufman Domains of Creativity Scale: Relationship to Occupation and Measurement Invariance across Gender. Preuzeto sa https://psyarxiv.com/p6xja/, 24. 5. 2021.

Mourgues, C., Tan, M., Hein, S., Elliott, J. G., \& Grigorenko, E. L. (2016). Using Creativity to Predict Future Academic Performance: An Application of Aurora's Five Subsets for Creativity. Learning and Individual Differences, 51, 378-386.

Naderi, H., Abdullah, R., Aizan, H. T., Sharir, J., \& Kumar, V. (2010). Relationship between Creativity and Academic Achievement: A Study of Gender Differences. Journal of American Science, 6 (1), 181-190.

Nami, Y., Marsooli, H., \& Ashouri, M. (2014). The Relationship between Creativity and Academic Achievement. Procedia - Social and Behavioral Sciences, 114, 36-39. doi: 10.1016/j.sbspro.2013.12.652

Pekic, J. (2011). Relacija kreativnosti i skolskog postignuca u kontekstu razlicitih akademskih domena. Primijenjena psihologija, 4 (3), 295-306.

Perleth, C., \& Sierwald, W. (1993). Selected results of the Munich longitudinal study of giftedness: The multidimensional / topological giftedness model. Roeper Review, 15 (3), 149-155.

Pinker, S. (2009). The sexual paradox: Men, women and the real gender gap. New York: Scribner. Pishghadam, R., Khodadady, E., \& Zabihi, R. (2011). Learner creativity in foreign language achievement. European Journal of Education Studies, 3 (3), 465-472.

Plucker, J. A. (1988). Beware of Simple Conclusions: The Case for Content Generality of Creativity. Creative Research Journal, 11 (2), 179-182. doi:10.1207/s15326934crj1102_8 
Potur, A. A., \& Barkul, O. (2009). Gender and creative thinking in education: A theoretical and experimental overview. Journal of the Faculty of Architecture, 6 (2), 44-57.

Priest, T. (2006). Self-evaluation, creativity, and musical achievement. Psychology of Music, 34 (1), 47-61. doi: 10.1177/0305735606059104

Runco, M. A., \& Bahleda, M. D. (1986). Implicit theories of artistic, scientific and averyday creativity. Journal of Creative Behavior, 20 (2), 93-98.

Ruth, J. E., Birren, J. E. (1985). Creativity in adulthood and old age: Relations to intelligence, sex, and mode of testing. International Journal of Behavioral Development, 8, 99-109.

Sahin, F. (2016). Kaufman Alanlari Yaraticilik Olcegi'nin Turkceye uyarlanmasi ve psikometrik ozelliklerinin incelenmesi [Adaptation of the Kaufman Domains of Creativity Scale into Turkish and examination of its psychometric properties]. Ilkoogretim Online, 15 (3), 855-867. DOI: 10.17051/io.2016.70479

Silvia, P. J., Kaufman, J. C., \& Pretz, J. E. (2009). Is creativity domain-specific? Latent class models of creative accomplishments and creative self-descriptions. Psichology of Aestetics, Creativity and the Arts, 3 (3), 139-148.

Silvia, P. J., Wigert, B., Reiter-Palmon, R., \& Kaufman, J. C. (2012). Assessing Creativity with SelfReport Scales: A Review and Empirical Evaluation. Psychology of Aesthetics Creativity and the Arts, 6 (1), 19-34. doi: 10.1037/a0024071

Silvia, P. J., Rodriguez, R. M., Beaty, R. E., Frith, E., Kaufman, J. C., Loprinzi, P., \& ReiterPalmon, R. (2021). Measuring everyday creativity: A Rasch model analysis of the Biographical Inventory of Creative Behaviors (BICB) scale. Thinking Skills and Creativity, 39, doi: 10.1016/j.tsc.2021.100797

Stojakovic, P. (2000). Darovitost i kreativnost. Srpsko Sarajevo: Zavod za udzbenike nastavna sredstva Republike Srpske.

Suzić, N. (2000). Dvadeset osam kompetencija za XXI vijek. Banja Luka: Republicki pedagoski zavod.

Tan, C. S., Tan, S. A., Cheng, S. M., Hashim, I. H. M., \& Ong, A. W. H. (2016). Factor Structure and Psychometric Qualities of the Kaufman Domains of Creativity Scale. International Conference on Education and Psychology (ICEduPsy16), 389-400, Kota Kinabalu, Sabah. Preuzeto

sa: https://www.academia.edu/30665340/Factor_Structure_and_Psychometric_Qualitie s_of_the_Kaufman_Domains_of_Creativity_Scale, 20.5.2021.

Treffinger, D. J. (1996). Creativity, creative thinking, and critical thinking: In search of definitions. Sarasota, FL: Center for Creative Learning.

Warren, G. H., \& Luria, Z. (1972). Evaluational set and creativity. Perceptual Motor Skills, 1 (2), 436-438.

Welsch, P. K. (1981). The nurturance of creative behavior in educational environments: A comprehensive curriculum approach. Dissertattion Abstracts International, 41 (9), 3870A, University of Michigan (University Microfilms No. 81-06456).

Werner, C. H., Tang, M., Kruse, J., Kaufman, J. C., \& Spörrle, M. (2014). The Chinese version of the Revised Creativity Domain Questionnaire (CDQ-R): First evidence for its factorial validity and systematic association with the Big Five. The Journal of Creative Behavior, 48 (4), 254-275. doi: $10.1002 /$ jocb. 51

Zheng, R., \& Xiao, B. (1983). A study on the creativity of high school students (Chinese). Acta Psychologica Sinica, 15, 445-452. 


\section{Biografske beleške o autorima:}

Sonja Kaurin je viši asistent na Katedri za pedagogiju, Filozofski fakultet Univerziteta u Istočnom Sarajevu i doktorand na Katedri za pedagogiju Filozofskog fakulteta u Banjoj Luci. Napisala je i objavila nekoliko naučnih i stručnih radova iz oblasti Opšte pedagogije, Metodologije pedagoških istraživanja i Inkluzivnog obrazovanja. Učesnik je nekoliko domaćih i međunarodnih projekata.

Ranka Perućica je doktor pedagoških nauka. Zaposlena je na Medicinkom fakultetu u Foči, Univerzitet u Istočnom Sarajevu. Autor je nekoliko naučnih radova iz oblasti Opšte pedagogije, Porodične pedagogije i Inkluzivnog obrazovanja. Aktivno učestvuje na domaćim i međunarodnim projektima, stručnim i naučnim skupovima i konferencijama. 